\title{
O PACOTE ANTICRIME NO TOCANTE ÀS FACÇÕES CRIMINOSAS, À LUZ DA TEORIA DO DIREITO PENAL DO INIMIGO, PONDERADA COM O GARANTISMO PENAL
}

\section{THE ANTICRIME PACKAGE FOR CRIMINAL GANGS, IN THE LIGHT OF THE THEORY OF THE ENEMY'S CRIMINAL LAW, PONDERED WITH CRIMINAL GUARANTEE}

\author{
Marcus Vinícius Alves de Oliveira ${ }^{1}$ \\ Pedro Sérgio dos Santos ${ }^{2}$
}

\section{RESUMO}

Inegável o avanço da atuação das facções criminosas no Brasil, o que gera hoje o maior fenômeno/problema a ser enfrentado pelas políticas de segurança pública, diante da estruturação organizada que dissemina o tráfico de drogas e crimes correlatos por todos os rincões do país. Essa criminalidade extrema leva a pensar que estaríamos diante do inimigo conceituado pela Teoria do Direito Penal do Inimigo, idealizado por Günther Jakobs, como sendo o sujeito ao qual não devem ser conferidos direitos fundamentais, por demonstrar o faccionado que está avesso à ressocialização, que seria um dos objetivos da pena, já que estaria somente voltado em incrementar cada vez mais a atuação criminosa organizada. Porém, em um estado democrático de direito, tal restrição de direitos seria inconcebível, conforme preleciona Ferrajoli (2014), mesmo em relação a um desviante extremo, sendo necessária a ponderação de conflitos diante do caso concreto, de modo a não afastar tais direitos. Como política pública de tentativa de controle das ditas organizações criminosas instaladas em presídios e que controlam o crime externamente, parte do pacote anticrime foi direcionada a elas, contendo dispositivos de maior coercibilidade frente a seu avanço. Nesse passo discute-se cada alteração para se verificar ofensa a direitos fundamentais ou se representariam medidas

\footnotetext{
${ }^{1}$ Mestrando em Direito e Políticas Públicas pelo Programa de Pós-Graduação em Direito e Políticas Públicas da Universidade Federal de Goiás (PPGDP/UFG). Magistrado. E-mail mvaoliveira@tjgo.jus.br. ORCID: 0000-0002-9935-5404

2 Doutor em Direito Público Processual Penal pela Universidade Federal de Pernambuco. Mestre em Direito Penal/Criminologia pela Universidade Federal de Pernambuco. Professor da Faculdade de Direito e do Programa de Pós-gradução em Direito e Políticas Públicas (PPGDP/UFG) da Universidade Federal de Goiás. E-mail: psergioufg@bol.com.br. ORCID https://orcid.org/0000-0002-1087-8314
} 
necessárias para garantia da ordem pública, sem afrontar a dignidade do ser humano, principalmente.

PALAVRAS-CHAVE: Pacote anticrime; Facções criminosas; Inimigo; Garantismo; Direitos humanos.

\section{ABSTRACT}

The advancement of the criminal gangs' activities in Brazil is undeniable, which today generates the biggest phenomenon / problem to be faced by public policies of public security, given the organized structure that disseminates drug trafficking and related crimes throughout the country. This extreme criminality leads us to think that we would be facing the enemy conceptualized by the Theory of Criminal Law of the Enemy, idealized by Günther Jakobs, as being the subject to whom fundamental rights should not be conferred, for demonstrating the faction that is averse to resocialization, which would be one of the objectives of the sentence, since it would only be aimed at increasing more and more organized criminal activity. However, in a democratic state of law, such a restriction of rights would be inconceivable, as Ferrajoli teaches, even in the face of an extreme deviation, requiring the consideration of conflicts in the specific case, so as not to rule out such rights. As a public policy of attempting to control said criminal organizations installed in prisons and which control crime externally, part of the anticrime package was targeted at them, containing devices of greater coercibility in the face of their advance. In this step, each change is discussed, in order to verify the offense to fundamental rights or if they would represent necessary measures to guarantee public order, without facing the dignity of the human being mainly.

KEYWORDS: Anti-crime package; Criminal gangs; Enemy; Guarantee; Human rights.

\section{INTRODUÇÃO}

De início, façamos uma conceituação e um breve histórico da ascensão das principais facções criminosas no Brasil.

Aduz-se que facções criminosas, como uma das vertentes do conceito de organizações criminosas, sejam grupos de pessoas em que se verificam relações de solidariedade e gregarismo, que surgiram nos presídios brasileiros e foram fundados prioritariamente sob o lema da defesa dos interesses da comunidade carcerária, tendo 
a prática de atos tipificados em lei como crimes como um de seus modos de atuação dentro e fora dos presídios (SHIMIZU, 2011).

Em 1993, na Casa de Custódia e Tratamento de Taubaté, em São Paulo, havia dissidências de dois grupos, e, em razão de críticas à administração do Presídio, esta permitiu um campeonato de futebol, liberando os presos para a mesma área comum e gerando conflito com mortes. Houve intervenção do Batalhão de Choque, mas sem sucesso num primeiro momento. Os líderes do Primeiro Comando da Capital (PCC) à época ficaram conhecidos como "os caras que dominaram a Casa de Custódia e Tratamento"; logo após tal fato, elaboraram o estatuto do grupo, estabelecendo pela primeira vez que o PCC era uma facção, e não uma quadrilha que explorava quem não tem organização, bem como formando o lema "Paz, Justiça e Liberdade" (TOGNOLLI; CHRISTINO, 2017).

Desde antes do referido episódio, já após a rebelião do Carandiru, em 1992, que resultou na morte de 111 presos por policiais, aqueceu-se o discurso de que os presos tinham que se unir contra o "sistema", referindo-se à atuação estatal nos presídios, a qual, desde 1960, vinha evidenciando violência contra os presos. Tal fato impulsionou a criação do Estatuto do PCC, que em seu $13^{\circ}$ artigo diz: "Porque nós do Comando vamos sacudir o sistema e fazer essas autoridades mudar a prática carcerária desumana, cheia de injustiça, opressão, tortura e massacres nas prisões" (MANSO; DIAS, 2017, p. 12).

Nesse sentido, Manso e Dias relembram informações de Caldeira (2000) e dizem, a respeito de São Paulo, que

[...] o mundo do crime serviu tanto para expressar os sentimentos de perda e de decadência social gerado pelas transformações estruturais quanto para legitimar a reação violenta por parte das autoridades como justificativa, mesmo que inconfessável, para o resgate de uma ordem passada aparentemente perdida (MANSO; DIAS, 2017, p. 13).

Já no Rio de Janeiro, diferentemente de São Paulo, as facções criminosas (notadamente o Comando Vermelho) surgiram no final dos anos $1970 \mathrm{com}$ o tráfico de forma territorializada nos morros (favelas), o que acarretou uma sociabilização 
extremamente violenta nessas comunidades dominadas, diante da disputa de mercado, investimento em armamento, ameaças à população, investidas policiais que tratam a sociedade como cúmplices do tráfico (ZALUAR, 1985).

O PCC surgiu em 1993 e desde então desafia autoridades de segurança pública, que chegaram a negar sua existência, mesmo depois de grande rebelião em $2001 \mathrm{e}$ ataques a autoridades em 2006, até que em 2017 pesquisadores e autoridades buscaram saber a fundo o que estava acontecendo, pois até então assistia-se passivamente a expansão dele, disseminando a conexão entre a prisão e o "mundo do crime".

Mais recentes demonstrações desse avanço são as rebeliões em presídios no Norte e no Nordeste em janeiro de 2017, que causaram mais de 160 mortes e mostraram uma nova sistemática do emaranhado articulado de organização e distribuição de drogas de dentro dos presídios para diversos rincões.

O aumento do encarceramento trouxe a organização dos crimes para dentro dos presídios, após perceberem que o tráfico de drogas e crimes conexos eram rentáveis, bem como por verem a prisão como terreno fértil para angariar novos adeptos e terem tempo para arquitetar a forma de ação coordenada de montar as "bocas de fumo" por todo o país, organizando-as financeiramente, com balanços de rentabilidade e distribuição de lucros.

Por intermédio da entrada de aparelhos celulares nos presídios, seja em partes íntimas de visitantes, por cima dos muros, por drones, por aves, por corrupção de carcereiros, etc., houve uma articulação muito maior das estratégias de disseminação e aumento da rede de pontos de venda de droga nas ruas, a partir da gerência realizada pelos "escritórios do crime" nos presídios, sob o lema "o crime fortalece o crime" (MANSO; DIAS, 2017).

Esse avanço na distribuição logicamente é motivado pelo aumento da necessidade de fornecimento, e esta se dá pelo aumento do uso. Esse panorama atual pode ser assim ilustrado: enquanto o consumo da cocaína vem registrando quedas sucessivas em nações da Europa Central, nos Estados Unidos e no Canadá, acompanhando a tendência de queda na produção da droga na Colômbia, o mercado consumidor na América do Sul, encabeçado pelo Brasil, teve aumento de mais de 50\% 
entre 2010 e 2012, segundo as pesquisas feitas pelo Escritório das Nações Unidas sobre Drogas e Crime, segundo relatório do UNODC (2016). O consumo de crack também se consolidou nacionalmente a partir do ano 2000. A pedra já provoca problemas em $98 \%$ das 3.950 cidades do Brasil mapeadas no estudo coordenado pela Confederação Nacional dos Municípios. O padrão de venda e consumo do crack, fumado em pequenas pedras, por usuários de baixa escolaridade e renda, torna a unidade mais barata e ajuda a viabilizar economicamente os negócios de entorpecentes nos bairros mais pobres dos Estados brasileiros, que acabam tendo de lidar com a realidade desse novo comércio (BASTOS; BERTONI, 2014).

Aliado a isso, temos a atratividade de novos adeptos a essa nova sistemática de enriquecimento ilícito, baseada no discurso ideológico de serem todos criminosos, de não haver motivo para disputas, e sim os encarcerados e os que atuavam externamente no "mundo do crime" fortalecerem-se mutuamente em prol da facção; isso causou arrefecimento das disputas e rebeliões nos presídios, e até proibição de uso de crack e outras regras de comportamento foram implantadas para que 0 ambiente fosse adequado à arquitetação criminosa.

Diante dessa demonstração de expressivo avanço das facções pelo Brasil e mundo é que necessária se faz a reflexão que esse trabalho propõe.

Então, o grande dilema passa a ser como combater efetivamente as facções criminosas, que são instituições declaradamente ofensivas à ordem pública, sem abandonar por completo as garantias do cidadão, mesmo este, no caso, sendo um desviante ao extremo.

\section{TEORIA DO DIREITO PENAL DO INIMIGO VERSUS GARANTISMO PENAL}

A Teoria do Direito Penal do inimigo, idealizada pela doutrina do alemão Günther Jakobs (2008), está há mais de 30 anos propagando entendimentos pelo mundo e alocando-os em várias situações; dentre elas, a incorporação de sua aplicação diante da atuação das facções criminosas brasileiras.

Dispõe a prática de um Direito Penal que separaria os delinquentes e criminosos em dois tipos: os primeiros continuariam a ter o status de cidadão e, uma vez que infringissem a lei, teriam ainda o direito ao julgamento dentro do ordenamento jurídico 
estabelecido e a voltar a ajustar-se à sociedade; os outros, no entanto, seriam chamados de "inimigos" do Estado e seriam adversários, representantes do mal, cabendo a estes um tratamento rígido e diferenciado por não conseguirem adaptar-se às regras da sociedade, sendo iminente neutralizar seu potencial ofensivo e prejudicial.

Segundo Jakobs (2008, p. 17), "quem não oferece segurança de que se comportará como pessoa não pode esperar ser tratado como pessoa, como tampouco o Estado está autorizado a tratá-lo ainda como pessoa, pois, de outro modo, estaria lesando o direito das outras pessoas à segurança".

Chega-se a conceituar a atuação das facções criminosas como narcoterrorismo, que seria a forma de terrorismo financiada pelo tráfico de drogas, especialmente para exploração dos lucros gerados por essa atividade. Insere-se no contexto da disputa entre facções rivais pelo controle de áreas de plantio e refino localizadas em zonas rurais e por mercados consumidores nos centros urbanos ou, ainda, é empregado como recurso operacional no embate contra órgãos de repressão estatais e forças de segurança pública (VISACRO, 2009).

Necessária uma ponderação da teoria do Direito Penal do Inimigo em face da atuação das facções criminosas que se instalaram nos presídios comandando o crime externamente, em contraponto à lesão dos direitos e garantias fundamentais.

Embasa que o indivíduo que não admite ser obrigado a entrar em um estado de cidadania não pode participar dos benefícios do conceito de pessoa. O terrorista rechaça a legitimidade do ordenamento jurídico e persegue a destruição dessa ordem. Quem inclui o delinquente como inimigo não deve assustar quando misturarem conceitos "guerra" e "processo penal".

Porém, necessário fixar se, e em que pontos, se justificaria a supressão/diminuição de direitos e implementação de rigor no tratamento em processos e em presídios, em razão de desviante integrar facções criminosas.

Esse distanciamento da realidade prisional para com o sistema constitucional relembra as penas proibidas pela Constituição Federal de 1988, notadamente quando veda que o cumprimento da sanção penal de privação de liberdade seja cruel (CF/88, art. 5o, XLVII). 
Em contraponto, temos vários princípios constitucionais que divergem do entendimento do direito penal do inimigo, dizendo-o incompatível com o ordenamento jurídico-constitucional brasileiro: A dignidade da pessoa humana, quando o inimigo deixa de ser tomado por pessoa; O princípio da culpabilidade e da presunção de inocência, de forma que o sistema penal constitucional não se baseia na periculosidade do agente, mas propaga que ninguém será considerado culpado senão por meio de sentença condenatória transitada em julgado, o contrário da culpabilidade como pressuposto da pena, por considerá-lo perigoso; Diz ferir também o princípio da retributividade, pelo qual não há pena sem crime, bem como o princípio da responsabilidade penal pelo fato, vez que há a necessidade da prática de um delito para que se possa aplicar a pena ao desviante.

Assim, o direito penal do inimigo contrariaria esses princípios, punindo o desviante antes do cometimento de crime, ou o encaixe de um fato por ele praticado em um tipo penal, ou punindo-o em virtude de qualidades pessoais.

Feriria também o devido processo legal, já que o estado democrático de direito brasileiro não autoriza rito procedimental sem ampla defesa e contraditório ao acusado, e pelo direito penal do inimigo não há razão para procedimento pois vige a Guerra; a isonomia também seria lesada, por não ser razoável diferenciar duas categorias de indivíduos: o cidadão e o inimigo.

Em contraposição a esse último, há quem entenda que o princípio da isonomia é relativizado pela hermenêutica jurídica, permitindo tratamento desigual. "O tratamento desigual dos casos desiguais, na medida em que se desigualam, é exigência tradicional do próprio conceito de Justiça" (MORAES, 2005, p. 31). Nesses casos ímpares, o Estado possui legitimação para aumentar o rigor repressivo para atender aos anseios sociais de harmonia e segurança.

Sendo cláusulas pétreas, não se permitiria a retirada desses preceitos do sistema, pois os direitos humanos são conquistas irreversíveis da humanidade, devendo ser banidas ou impedidas previsões que estabeleçam abolição ou diminuição de direitos fundamentais, mas ainda persiste o problema de como resolver a desenfreada ofensiva das facções criminosas que pode chegar ao ponto de inviabilizar o convívio seguro em sociedade em níveis toleráveis. 
Assim, o que se discute é saber se os direitos dos cidadãos podem ser diminuídos para individualizar os inimigos, discutindo algo diferente da própria eficácia da proposta de contenção. Caso se legitime essa ofensa aos direitos, concede-se ao poder a faculdade de estabelecer até que ponto será necessário limitar os direitos para exercer um poder que está em suas próprias mãos, e, assim, se isso ocorrer, O Estado de Direito terá sido abolido (ZAFFARONI, 2007).

Ressalta-se a ideia central de enfrentar a criminalidade organizada, mas não descurando dos referidos princípios, que dão segurança jurídica ao estado democrático de direito.

\section{MEDIDAS DE CONTENÇÃO DAS FACÇÕES}

Pelo noticiário já se percebe claramente a atuação das facções de forma a causar criminalidade exacerbada, diferente da comum, diante dos relatos de homicídios contra rivais, roubos para manutenção financeira das organizações, incêndios a transportes coletivos para demonstração de força contra o Estado, ataques a postos policiais, rebeliões e fugas de presídios, explosões de caixas eletrônicos, atentados contra policiais e identificação de imóveis de luxo e de outros bens de criminosos obtidos por meio do lucro de seus ilícitos.

Neste cenário agrava-se enormemente a criminalidade em comparação à dita "'normal", o que enseja sensação de insegurança acima de níveis psicologicamente aceitáveis; tendo como exemplos, várias cidades no Brasil têm quantidade proporcional de homicídios se comparadas às mais violentas do mundo, equivalentes ao de uma zona em conflito, segundo o relatório do Consejo Ciudadano para la Seguridad Pública y Justicia Penal A.C (2018). Das 50 (cinquenta) cidades mais violentas, 17 (dezessete) são brasileiras.

Assim, permeia a sensação clara de que o Estado não consegue ressocializar os criminosos, que muitas vezes voltam a delinquir, e tampouco é capaz de manter tais indivíduos fora do convívio social, o que gera clamor social por uma atuação estatal capaz de dar uma resposta contundente a esse novo e agressivo modelo ofensivo criminoso. 
Daí iniciam-se discussões no Congresso Nacional para liberação de porte de arma, aumento do rol dos crimes hediondos, redução da maioridade penal e projetos para punição ou aplicação de regime de cumprimento de pena de forma mais rigorosa para agentes de facções, como foi o projeto denominado Pacote anticrime.

Nesse diapasão, necessária uma discussão sensata sobre quais sejam os meios eficazes no combate às mais diversas modalidades de ações criminosas organizadas, que envolvem os mais variados e violentos tipos criminais.

Essa busca de medidas eficazes para contenção das facções certamente é o maior desafio da área de segurança pública no país, diante da complexidade de atuação e organização das facções, como exemplo: reorganização rápida com inclusão de novos membros após prisão, apreensão de drogas ou descoberta de pontos de vendas; manutenção financeira e de proteção das comunidades onde se instalam; vasta comunicação por telefones celulares, por cartas de visitantes familiares e outros; capacidade plena de controle dos crimes fora dos presídios, sem possibilidade razoável de ação antecipada das polícias; atratividade da juventude para se tornar membro diante do sonho do dinheiro fácil; desorganização estratégica estatal; constante fomento das facções para manutenção do poderio econômico de venda de drogas, com aquisição de armas de alto poder ofensivo, corrupção institucionalizada e lavagem de dinheiro por atividades aparentemente lícitas.

Vemos ainda que a instituição penal é estruturalmente incapaz de dominar completamente a massa de internos e que a administração é induzida a abrir-se às lideranças informais dos presídios, negociando e fazendo concessões, a fim de manter um nível satisfatório de controle sobre a população sob sua responsabilidade.

O controle do Estado, em alguns casos, faz vista grossa quanto ao âmbito interno prisional, diante da dificuldade de controle e pelas vantagens diretas e indiretas daí advindas, ao permitir e/ou participar das ilegalidades ali ocorridas, resultantes da corrupção no meio prisional ou até da pacificação resultante do próprio Estatuto das facções. Indiretamente, a vantagem está no fato de a multidão confusa continuar sob controle, ainda que esse controle advenha do poder das facções - o que pode significar um grande risco ao Estado quando há um desequilíbrio desse arranjo de poder (Estado - facções) (BRAGA, 2008, citado por SHIMIZU, 2011). 
A interligação e a dependência entre as facções (Poder paralelo) e o Estado também se verificam na atuação desses grupos fora dos limites do cárcere, em favelas e bairros de periferia, nos quais igualmente se constatam a corrupção, as negociações e as concessões, que mantêm um equilíbrio espúrio entre as instâncias de poder.

Mesmo diante dessa enorme dificuldade de contenção, o Estado não se omitiu e procurou estabelecer algumas medidas inteligentes para diminuição do poderio das facções.

A Lei 12.850/2013 (Lei das Organizações Criminosas) foi importante para dar conceito à "Organização Criminosa" e também por trazer a previsão de importantes meios para obtenção de provas.

Um desses meios seria a delação premiada, quando um membro pode obter perdão do delito ou redução da pena ao contribuir com os resultados de obtenção de prova da organização e de atuação de seus membros.

Também como meio eficaz temos a ação controlada, que é espécie do flagrante retardado, quando o agente estatal aguarda momento oportuno para agir, que não é no momento da descoberta do crime, tendo resultado mais eficaz.

Temos ainda a figura do agente infiltrado, que é introduzido dissimuladamente na organização para obtenção de provas e informações que permitam detectar a forma de atuação e assim melhor reprimir.

A intitulada pirâmide minimalista faz gradação entre os crimes: os menos graves (na base da pirâmide) deveriam ter seus tipos penais revogados, para que os bens jurídicos que almejam proteger o sejam por outros ramos do direito; os mais graves, de outro lado - posição na qual figuraria a criminalidade organizada -, permaneceriam sob o manto do direito penal e das mais duras penas privativas de liberdade. Uma faixa intermediária na pirâmide representaria o incremento da atuação dos juizados especiais criminais e um maior uso das penas alternativas.

Desta feita, por um lado, defende-se a intervenção efetiva do Estado no controle social, aí incluído o controle sobre a criminalidade, legitimando a criação de normas mais rigorosas e a adoção de medidas públicas de efetiva contenção. Por outro, entende-se que essa intervenção estatal há de ser mínima, garantindo-se, assim, maior liberdade ao indivíduo, como membro do grupo social, que não deve ser 
completamente alijado ou isolado, mesmo que venha a praticar condutas consideradas lesivas aos direitos penalmente tutelados.

Porém, logicamente incabível à criminalidade organizada a aplicação do direito penal mínimo no sentido de punições ou coerções brandas, em razão da notória inutilidade para seu controle.

\section{PONDERAÇÃO DAS SITUAÇÕES AFETAS ÀS FACÇÕES CRIMINOSAS}

Passamos então à ponderação das situações envolvidas.

Entendo como questão a ser observada a correta identificação do membro da facção, seja por listas e cadernos apreendidos em Presídios e em pontos de venda de drogas, aliada a, por exemplo, fotos ou vídeos em que ele esteja em condição própria de desempenhar papel importante dentro da facção, bem como por escutas telefônicas em que desenvolva conversas típicas de controle de ações coordenadas, diferentes de ações individuais de criminoso comum ou ainda preso em flagrante em situação de plena coordenação em esquema de tráfico de drogas com considerável ramificação e estrutura.

A partir daí, com prova reforçada em mais de um elemento de convicção, garantir-se-ia não estar enquadrando o desviante apenas presumidamente como membro de facção, o que poderia ferir o direito de sofrer imposição do direito penal proporcional ao que se afigura realmente.

Assim se poderia enquadrar a conduta do desviante ao extremo somente no que é típico no direito penal, seja no Código Penal ou em leis esparsas, que possuem gama bem abrangente de condutas, não sendo permitido fazer subsunção a tipos mais rigorosos do que efetivamente consistiu a conduta do membro da facção, sob pena de ferir o princípio da legalidade e tipicidade.

Alguns criticam a possibilidade excepcional de tipificação de atos preparatórios enquadráveis como típicos de organização criminosa, como dispõe o artigo 5ํㅡㄹ da Lei ํo 13.260/16 (Lei antiterrorismo), pelo qual será considerado crime, inclusive, a prática pelo agente de atos preparatórios ao terrorismo, quando demonstrada a sua intenção de consumação do delito, tendo clara intenção de evitar a ocorrência efetiva de 
condutas terroristas, antecipando-se à consumação do delito, o que pode até ser considerado apto ao fim a que se destina, se houver interpretação não punitivista.

Assim, são exceções à regra que os atos preparatórios não são puníveis no sistema jurídico penal pátrio, verificando naqueles casos em que o legislador opta por tipificar, desde logo, a conduta preparatória como crime autônomo.

Na Lei 13.260/16, vê-se dois exemplos dessa criminalização:

1) Integração da Organização Terrorista: uma primeira punição de atos que não necessitam de resultado material (crimes formais) reveste de técnica legislativa já conhecida no sistema penal brasileiro, em que se pune o fato de o agente integrar a organização que tenha como finalidade a prática de crime. A exemplo desta forma de tipificação, tem-se a inserida no artigo 288 do Código Penal, correspondente à associação criminosa, assim como a prevista na Lei 12.850/13, consistente em integrar organização criminosa. Mesmo que a referida organização e o agente não venham a praticar delitos (finalidade precípua da organização/associação), o simples fato de integrá-la já configura delito punível em nosso ordenamento, haja vista o perigo representado por essa forma de agrupamento. O simples animus associandi já corresponde à lesão a bem jurídico tutelado, por isso merecedor de tipificação autônoma.

2) Prática de atos de terrorismo: Art. $3^{\circ}$ : Promover, constituir, integrar ou prestar auxílio, pessoalmente ou por interposta pessoa, a organização terrorista: Pena reclusão, de cinco a oito anos, e multa.

Assim, fazendo um paralelo entre atos de terrorismo e atos de facções criminosas, percebe-se a necessidade de aplicação de institutos diferenciados para tratar criminalidade extrema, como é o caso da punição de atos preparatórios, que, se forem adequadamente interpretados e provados, não ensejariam deliberadamente e por si só em ofensa ao princípio da legalidade e taxatividade, diante da propensão à prática de crimes em favor da facção.

Porém, no caso do enquadramento da Lei de organizações criminosas, trata-se de punição por ser membro de organização criminosa, da qual facção criminosa é espécie, independente da prática de algum ato ou omissão, por política criminal de 
proteção contra a atividade criminosa extrema, sendo prudente, então, que se faça a devida identificação, conforme acima dito.

Isso porque aguardar a efetiva ofensiva do membro da facção, que como integrante se presume predisposição à pratica de crimes ditados pela facção, pode implicar em desajuste excessivo da ordem pública, dependendo do caso concreto, sendo prudente evitar o ocorrido com seu enquadramento punível antes que isso ocorra, razão pela qual, nesta análise, há possibilidade de existência do instituto, se bem aplicado, sem ofensa aos direitos e garantias fundamentais.

\section{PACOTE ANTICRIME NO TOCANTE ÀS FACÇÕES CRIMINOSAS}

A Lei 13.964/2019, intitulada de "pacote anticrime" e idealizada pelo Governo atual, fez alterações no sistema penal, que causaram controvérsia, por supostamente ferir direitos e garantias fundamentais. Passamos, então, a discorrer sobre o que se relaciona com facções criminosas.

O artigo 91, § 5º, do Código Penal, incluído pela referida Lei, dispõe:

[...] os instrumentos utilizados para a prática de crimes por organizações criminosas e milícias deverão ser declarados perdidos em favor da União ou do Estado, dependendo da Justiça onde tramita a ação penal, ainda que não ponham em perigo a segurança das pessoas, a moral ou a ordem pública, nem ofereçam sério risco de ser utilizados para 0 cometimento de novos crimes.

Esse dispositivo elenca preocupação em impossibilitar o retorno de instrumentos do crime para as facções, a fim de que diminua seu poderio ofensivo e afete economicamente a facção.

A prática demonstra que as formas mais inteligentes de combate às facções são o isolamento de comunicação e diminuição do poderio econômico (MANSO; DIAS, 2018). Assim, se realizada a devida apuração, não se afigura viável fundamentar-se no direito de propriedade do instrumento, requerendo sua restituição, já que na outra face da situação encontra-se a ordem pública, além do que o objeto estaria a serviço do crime, não tendo motivo para amparo pelo ordenamento jurídico e nem se estaria simplesmente retirando direitos por ser considerado inimigo. 
O artigo 310, $\S 2^{\circ}$, do Código de Processo Penal, incluído pela referida Lei, dispõe: "se o juiz verificar que o agente é reincidente ou que integra organização criminosa armada ou milícia, ou que porta arma de fogo de uso restrito, deverá denegar a liberdade provisória, com ou sem medidas cautelares".

A expressão impositiva deverá denota a intolerância na análise sobre concessão de liberdade provisória, diante da gravidade que se considera do membro de facção criminosa, de forma generalizada, mas na prática pode ocorrer que este sujeito pode ter se envolvido isoladamente, uma única vez, conseguido se desvencilhar da facção, provando intenção de seguir caminho diferente e correto na vida, e ter predicados pessoais que demonstrem possibilidade de concessão da liberdade, sem que afete efetivamente a ordem pública, razão pela qual tal expressão se demonstra rigorosa ao extremo e generalista.

Ademais, inoportuna a indicação da impossibilidade de análise dos requisitos do artigo 312 do Código de Processo Penal, que versa sobre a prisão preventiva, pois em regra no nosso ordenamento jurídico vige a liberdade provisória, sendo a prisão preventiva exceção quando previsto algum dos requisitos ali previstos.

O artigo 52 da Lei de Execução Penal, com as alterações da nova lei referida, passaram a ter a seguinte redação:

A prática de fato previsto como crime doloso constitui falta grave e, quando ocasionar subversão da ordem ou disciplina internas, sujeitará o preso provisório, ou condenado, nacional ou estrangeiro, sem prejuízo da sanção penal, ao regime disciplinar diferenciado, com as seguintes características:

I - duração máxima de até 2 (dois) anos, sem prejuízo de repetição da sanção por nova falta grave de mesma espécie;

II - recolhimento em cela individual;

III - visitas quinzenais, de 2 (duas) pessoas por vez, a serem realizadas em instalações equipadas para impedir o contato físico e a passagem de objetos, por pessoa da família ou, no caso de terceiro, autorizado judicialmente, com duração de 2 (duas) horas;

IV - direito do preso à saída da cela por 2 (duas) horas diárias para banho de sol, em grupos de até 4 (quatro) presos, desde que não haja contato com presos do mesmo grupo criminoso;

$\mathrm{V}$ - entrevistas sempre monitoradas, exceto aquelas com seu defensor, em instalações equipadas para impedir o contato físico e a passagem de objetos, salvo expressa autorização judicial em contrário;

VI - fiscalização do conteúdo da correspondência; 
VII - participação em audiências judiciais preferencialmente por videoconferência, garantindo-se a participação do defensor no mesmo ambiente do preso.

$\S 1^{\circ}$ - O regime disciplinar diferenciado também será aplicado aos presos provisórios ou condenados, nacionais ou estrangeiros:

II - sob os quais recaiam fundadas suspeitas de envolvimento ou participação, a qualquer título, em organização criminosa, associação criminosa ou milícia privada, independentemente da prática de falta grave.

$\S 3^{\circ}$ Existindo indícios de que o preso exerce liderança em organização criminosa, associação criminosa ou milícia privada, ou que tenha atuação criminosa em 2 (dois) ou mais Estados da Federação, o regime disciplinar diferenciado será obrigatoriamente cumprido em estabelecimento prisional federal.

$\S 4^{\circ} \mathrm{Na}$ hipótese dos parágrafos anteriores, o regime disciplinar diferenciado poderá ser prorrogado sucessivamente, por períodos de 1 (um) ano, existindo indícios de que o preso:

II - mantém os vínculos com organização criminosa, associação criminosa ou milícia privada, considerados também o perfil criminal e a função desempenhada por ele no grupo criminoso, a operação duradoura do grupo, a superveniência de novos processos criminais e os resultados do tratamento penitenciário.

$\S 5^{\circ} \mathrm{Na}$ hipótese prevista no $\S 3^{\circ}$ deste artigo, o regime disciplinar diferenciado deverá contar com alta segurança interna e externa, principalmente no que diz respeito à necessidade de se evitar contato do preso com membros de sua organização criminosa, associação criminosa ou milícia privada, ou de grupos rivais.

Aqui vemos outra situação que aparentemente poderia configurar ofensa ao direito do desviante extremo em ficar preso no presídio local do cometimento do fato, com a transferência de membros de facções criminosas para presídios regionais de segurança máxima, o que poderia causar distanciamento da família e restrição de visitas para aqueles que teriam pessoas próximas para tanto.

Aí se pondera a necessidade de isolamento do faccionado com o direito de convivência familiar. Observa-se na prática administrativa penitenciária a constante transferência de lideranças e membros de facções para unidades prisionais mais adequadas ao isolamento em relação à comunicação extramuros mais fácil. $A$ experiência mostra que a existência de faccionados em todas ou várias unidades prisionais gera descontrole, por não existir em todas elas estrutura adequada de contenção de comunicação, por aparelhos celulares ou por entrega de correspondência, onde também não há meios mais modernos de evitar ingresso de 
drogas e armas ou artefatos indevidos no ambiente carcerário (body scan), bem como gera cooptação fácil de novos membros antes não faccionados.

Assim, difícil conciliar esses interesses envolvidos, então na prática acaba-se exigindo maior esforço da família para se deslocar por distâncias maiores até o presídio regional de maior segurança ou até para se mudar para a cidade onde o faccionado se encontra. Tal situação é mobilizada pela logística referida em prol da segurança pública, mas, em casos pontuais de maior necessidade de acompanhamento familiar ou de predicados pessoais do apenado, demonstrando não estar ativo na facção, pode-se pensar em retorno ao presídio do local da condenação.

Outra situação dos dispositivos alterados transcritos refere-se ao Regime Disciplinar Diferenciado (RDD), instituído pela Lei 10.792/2003, que alterou a Lei 7.210/1984 (Lei de Execuções Penais); ele é uma forma de cumprimento de pena em regime fechado de forma mais rigorosa e custosa, consistindo em sanção disciplinar ao apenado quando for verificado apresenta alto risco para a ordem e a segurança do estabelecimento penal ou da sociedade, ou se sob o preso recaiam fundadas suspeitas de envolvimento ou participação em Organizações Criminosas, quadrilha ou bando, sendo medida atribuída pela periculosidade do desviante; é fato, contudo, que, mesmo diante de colocação em situação de segurança máxima, membros e chefes de facções conseguem comunicação e arquitetação criminosa externa.

Assim, esses dois requisitos servem para mostrar que o instituto é pautado pela periculosidade atribuída ao encarcerado, o que coaduna com as características atribuídas pela Teoria do Direito Penal do Inimigo.

As alterações da Lei 13.964 referentes ao Regime Disciplinar diferenciado foram no sentido de aumentar o tempo de duração no Regime, de até 01 (um) ano para até 02 (dois) anos, aumentar de semanalmente para quinzenalmente as visitas familiares e ainda estabelecer que devem ser realizadas em instalações equipadas para impedir o contato físico e a passagem de objetos.

No tocante ao tempo de duração, necessária uma apuração muito minuciosa e devidamente provada, após contraditório e ampla defesa, de situação que indique necessidade dessa segregação excessiva, que é o Regime Disciplinar Diferenciado, por 
esse período, de modo que fique claro que em outra situação realizaria efetivamente atos de liderança concreta em facção criminosa.

Em caso contrário, estaríamos diante de prisão com rigor desmotivado, ofensiva ao princípio da dignidade da pessoa humana em uma de suas formas mais agressivas.

Quanto ao impedimento de visitas familiares com contato físico para se evitar a passagem de objetos, tal medida poderia ter sido idealizada de forma a permitir o contato afetivo físico com o familiar, como sendo conduta respeitadora de sentimento dos mais nobres do ser humano, e, para evitar o risco de entrega de drogas ou objetos, que se realizasse visita com revista e monitorada.

No entanto, a Lei preferiu a vedação total do contato físico, diante da dificuldade estrutural de efetivar tal revista monitorada e por entender que o desviante de facção criminosa tem predisposição aos afastamento definitivo do convívio social e familiar, mas tais situações que geram distanciamento familiar impedem a possibilidade, não comum mas real, de que o desviante possa refletir por novos caminhos na vida após o afeto de seus familiares.

A Lei 11.671/2008, que dispõe sobre a transferência e inclusão de presos em estabelecimentos penais federais de segurança máxima, passou a vigorar com as seguintes alterações feitas pela Lei 13.964/2019:

Artigo 3:

$\S 1^{\circ} \mathrm{A}$ inclusão em estabelecimento penal federal de segurança máxima, no atendimento do interesse da segurança pública, será em regime fechado de segurança máxima, com as seguintes características:

I - recolhimento em cela individual;

II - visita do cônjuge, do companheiro, de parentes e de amigos somente em dias determinados, por meio virtual ou no parlatório, com o máximo de 2 (duas) pessoas por vez, além de eventuais crianças, separados por vidro e comunicação por meio de interfone, com filmagem e gravações;

III - banho de sol de até 2 (duas) horas diárias; e

IV - monitoramento de todos os meios de comunicação, inclusive de correspondência escrita.

$\S 2^{\circ}$ Os estabelecimentos penais federais de segurança máxima deverão dispor de monitoramento de áudio e vídeo no parlatório e nas áreas comuns, para fins de preservação da ordem interna e da segurança pública, vedado seu uso nas celas e no atendimento advocatício, salvo expressa autorização judicial em contrário. 
$\S 3^{\circ}$ As gravações das visitas não poderão ser utilizadas como meio de prova de infrações penais pretéritas ao ingresso do preso no estabelecimento.

Dentre as alterações estabelece-se a possibilidade de gravação audiovisual no parlatório e nas áreas comuns para fins de segurança, vedado no atendimento por advogado, o que é de bom tom para que a ordem pública e integridade física sejam preservadas em caso, por exemplo, de rebelião ou agressão a presos, mas preserva o sigilo das conversas do advogado.

Isso porque o direito amplo de defesa é previsto no artigo 5o, inciso LV, da Constituição Federal como princípio e direito fundamental, sendo relativizado pela lei acima somente por autorização judicial, por exemplo quando efetivamente provado que procurador está levando informações extramuros de coordenação criminosa da facção, o que não seria desarrazoado, pois estaria funcionando como membro de facção, e não defensor exclusivamente.

Indo à próxima alteração da Lei em questão, o artigo 112 da Lei de Execução Penal passou a essa disposição:

A pena privativa de liberdade será executada em forma progressiva com a transferência para regime menos rigoroso, a ser determinada pelo juiz, quando o preso tiver cumprido ao menos:

$\mathrm{VI}-50 \%$ (cinquenta por cento) da pena, se o apenado for:

b) condenado por exercer o comando, individual ou coletivo, de organização criminosa estruturada para a prática de crime hediondo ou equiparado; [...].

Tal dispositivo incluiu nova regra de progressão de regime de apenado membro de facção criminosa pelo tempo de $50 \%$ da pena, motivada por entender que esse desviante não merece possibilidade de mais rápido retorno ao convívio social, que é o principal objetivo da progressão de regime.

Isso porque faz a presunção de que o membro de facção não quer ser reintegrado socialmente por estar envolvido com a continuidade e crescimento da facção e não quer ter vida de cidadão de bem, além da intenção normativa de ficar mais tempo recluso para que a segurança pública seja mantida por período maior. 
Tal situação poderia ser amenizada por estudo de histórico do apenado e exame criminológico para que se verificasse efetiva e contínua participação nos deslindes de facção ou intenção demonstrada de não mais participar da organização, e sim seguir vida não mais desalinhada do que se espera no convívio externo.

O art. 1ํ da Lei 8.072/1990, com a alteração da Lei 13.964/2019, passou à seguinte redação:

Parágrafo único: Consideram-se também hediondos, tentados ou consumados:

$[\ldots]$

V - o crime de organização criminosa, quando direcionado à prática de crime hediondo ou equiparado.

Crime hediondo seria aquele que causa horror, é repulsivo, horrível, que causa grande indignação. Essa alteração passou então a catalogar como hediondo quem se organiza criminosamente para a prática de algum outro crime hediondo. Na prática, vemos notícia de facções criminosas praticarem tráfico de drogas e homicídio qualificado de rivais, por exemplo, o que se enquadra em tal dispositivo e acarreta maior rigor penal, por política criminal mais ostensiva contra tais práticas.

Logicamente não se poderia tratar com mesmas regras e mesmas penas quem demonstra criminalidade exacerbada na forma organizada e contínua, num propósito claro de não se arrefecer frente ao Estado, razão pela qual não parece medida desarrazoada este enquadramento de tal crime como hediondo.

\section{CONSIDERAÇÕES FINAIS}

Diante dessa explanação, verificamos a necessidade do desafio da ponderação dos interesses envolvidos, quando se falar em rigor na aplicação de medidas oriundas do entendimento do direito penal do inimigo, mas sem deixar de aplicar os direitos e garantias individuais que compõem o estado democrático de direito.

Nessa análise, não podemos deixar de refletir a segurança pública como um direito essencial ao ser humano, conforme artigo 5º, caput, e artigo 144 da Constituição 
Federal, em paralelo aos direitos e garantias do desviante penal, mas haverá momentos em que a balança penderá um pouco mais à proteção de um lado e às vezes de outro, não havendo que se falar em preponderância de nenhum deles.

Não se trata de virar os olhos contra os direitos fundamentais nos casos acima dispostos, mas equilibrá-los com situações justificadas que indiquem necessidade de sua mitigação momentânea e pontual, desde que devidamente fundamentada em situações concretas que denotem que, caso se opte em não aplicar tal exceção, haverá um avanço exacerbado e perigoso das organizações criminosas.

Isso não significa aplicação da controversa teoria do direito penal do inimigo de forma pura e simples, pois as regras acima analisadas conseguem conviver em um estado democrático de direito sem ofensa irrestrita aos direitos fundamentais, já que em nenhuma das análises se nega a qualquer desviante a condição de sujeito de direitos.

Assim sendo, as políticas públicas pensadas para a atuação contra a criminalidade excessiva das facções criminosas devem ser robustecidas de poder coercitivo maior do que as políticas públicas pensadas para o crime comum, sem que isso importe necessariamente em desrespeito excessivo aos direitos e garantias individuais do desviante extremo, ao qual são direcionadas medidas estatais proporcionais à sua atuação extraordinariamente ofensiva.

\section{REFERÊNCIAS}

BASTOS, Francisco Inácio Pinkusfeld Monteiro; BERTONI, Neilane (Orgs.). Pesquisa nacional sobre o uso de crack: quem são os usuários de crack e/ou similares do Brasil? quantos são nas capitais brasileiras? Rio de Janeiro: ICICT, 2014.

CONSEJO CIUDADANO PARA LA SEGURIDAD PÚBLICA Y JUSTICIA PENAL A.C. Las 50 Ciudades Más Violentas del Mundo 2017. Ciudad de México: Seguridad, Justicia y Paz, 2018.

FERRAJOLI, Luigi. Direito e razão. 4. ed. São Paulo: Revista dos Tribunais, 2014.

JAKOBS, Günther. Direito penal do inimigo. Noções e Críticas. Porto Alegre: Livraria do advogado, 2008. 
MANSO, Bruno Paes; DIAS, Camila. A guerra: a ascensão do PCC e o mundo do crime no Brasil. São Paulo: Todavia, 2018.

. PCC, sistema prisional e gestão do novo mundo do crime no Brasil. Revista brasileira de segurança pública, São Paulo, v. 11, n. 2, p. 10-29, ago./set. 2017.

MORAES, Alexandre de. Direito constitucional. 18. ed. São Paulo: Atlas, 2005.

SHIMIZU, Bruno. Solidariedade e Gregarismo nas facções criminosas: um estudo criminológico à luz da psicologia das massas. 2011. Dissertação (Mestrado em Direito) - Universidade de São Paulo, São Paulo, 2011.

TOGNOLLI, Cláudio, CHRISTINO, Mário Sérgio. Laços de sangue. A História Secreta do PCC. 2. ed. São Paulo: Matrix, 2017.

UNODC. The United Nations Office on Drugs and Crime. World drug report 2016. New York, 2016.

Disponível em: <https://www.unodc.org/doc/wdr2016/WORLD_DRUG_REPORT_2016_web.pdf>. Acesso em: 20 abr. 2020.

VISACRO, Alessandro. Guerra irregular: terrorismo, guerrilha e movimentos de resistência ao longo da história. São Paulo: Contexto, 2009.

ZAFFARONI, Eugenio Raul. Inimigo no direito penal. Rio de Janeiro: Revan, 2007.

ZALUAR, Alba. A máquina e a revolta: As organizações populares e o significado da pobreza. São Paulo: Brasilense, 1985. 